\title{
The Highlands of Contemporary Guatemala \\ by
}

\author{
Jeffrey S. Smith \\ Photography by the author
}

Imagine yourself strolling down a cobblestone street past $16^{\text {th }}$ and $17^{\text {th }}$ century Catholic cathedrals draped in brilliant bougainvillea all laying at the foot of a towering volcano (Figure 1). A surreal scene such as this is what helped Antigua, Guatemala earn the distinction of being the best-preserved Spanish colonial city in the Western Hemisphere. After being designated in 1543 as Spain's regional capital for Central America, Antigua grew in prominence to become the crown's third most important city in the New World after Mexico City and Lima, Peru. During its colonial heyday, between 1720 and 1773, Antigua boasted over 30 churches, 18 convents and monasteries, 15 hermitages, 10 chapels, 5 hospitals, a major university, and a well-developed public infrastructure. Adhering to the Laws of the Indies, John Mitchell asserts that Antigua was the first completely planned city in the Americas. Italian architect Juan Bautista Antonelli designed the city in 1541. Radiating out from the Plaza de Armas (central plaza), the town adheres to a rigid grid pattern. In 1773 , an earthquake again destroyed the city forcing government officials to move Spain's regional capital to Guatemala City. Ironically, the abandonment of Antigua was a blessing in disguise, because it prevented major architectural renovations from eliminating the colonial qualities of the city. Although never completely abandoned, Antigua did not become popular again among local Guatemalans until the middle of the $20^{\text {th }}$ century. By then, the federal government had designated the city a national treasure, and efforts were well underway to preserve its colonial charm.

With a current population of around 32,000 people, Antigua rests in the picturesque Panchoy valley and covers roughly the same geographic area as it did during its colonial golden era. In 1979, Antigua's unparalleled architecture and splendid setting earned it a place on UNESCO's (United Nations Educational, Scientific, and Cultural Organization) list of World Heritage Sites. As UNESCO

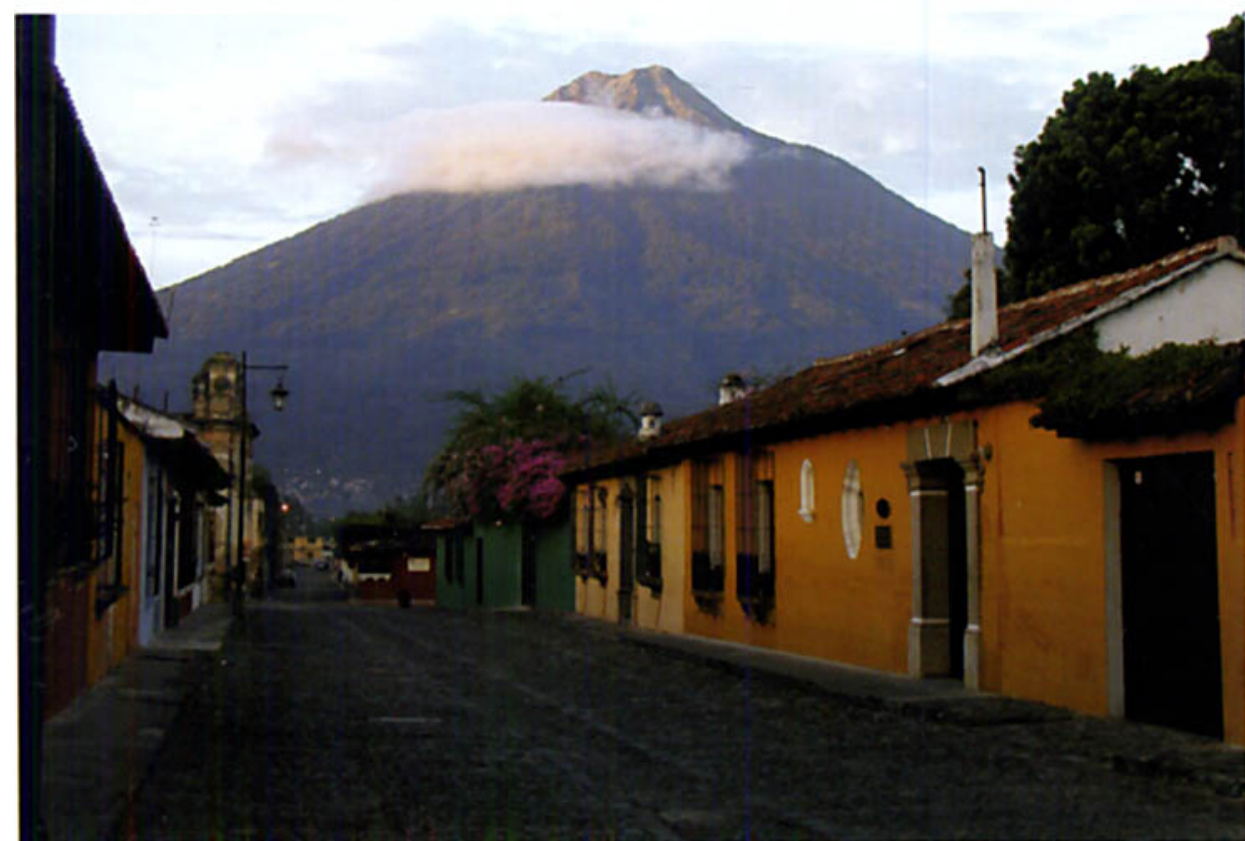

Figure 1: A typical street scene in Antigua, Guatemala. Antigua was founded on March 10, 1543 and first named La Muy Noble y Muy Leal Ciudad de Santiago de los Caballeros de Guatemala (the Most Nobel and Most Loyal City of St. James of the Knights of Guatemala) or La Antigua for short. In the background lies Agua Volcano (3,765 meters above sea level).

indicates on its web site, Antigua is among the organization's 788 cherished places because of its outstanding universal value. Its spectacular physical setting and rare architecture holds special cultural and social significance to the world community. Today, Antigua has at least 75 Spanish language immersion schools and has become a popular tourist destination for travelers throughout the world. As the world community focuses its attention on Antigua, many other lesser known but equally compelling villages throughout the highlands of Guatemala are going largely unnoticed and await discovery.

In May of 2004, geographers from throughout North and South America gathered in Antigua for that year's Conference of Latin Americanist Geographers (CLAG) meeting. This gathering afforded conference attendees the opportunity to learn from local experts conducting research in the area, listen to professional paper presentations, and explore Guatemala's volcanic highlands ${ }^{1}$. This article discusses three themes that characterize the contemporary highland region of Guatemala. It begins by discussing the influence that volcanoes have on Guatemalan life and then turns to exploring the manifestations of the Mayan Indian culture and the repercussions of a 36-year civil war.

1 In conjunction with the 2004 CLAG Conference, I participated in four field trips (two formal and two informal) that provided a detailed transect through Guatemala's south-central highlands between Guatemala City and Lake Atitlan. The two formal field trips were led by Taylor Mack, Michael Steinberg, and Matthew Taylor. Participants in the two informal field trips included Daniel Arreola, Richard Bein, and Susan Sargent. 


\section{Volcanoes}

Guatemala's physical geography is bifurcated regionally (Figure 2 ). Northern Guatemala is comprised of lowlands that extend into Mexico's Yucatan peninsula and Belize a region commonly referred to as the Peten. Two-thirds of Guatemala, however, is dominated by volcanic uplands. The central and southern portion of Guatemala is part of the extensive Central American Volcan Axis that extends from the highlands of southern Mexico through Guatemala, El Salvador, Honduras, Nicaragua, and Costa Rica. Guatemala has more than 35 volcanoes, the tallest being Volcano Tajumulco, which rises to a height of 4,221 meters $(13,845$ feet $)$ above sea level.

One of the most dramatic and scenic highlights of Guatemala's volcanic upland region is found around Lake Atitlan. Volcanic activity in this area began approximately 12 million years ago and progressed through four major episodic eras leading to its current geologic configuration. In that time, a succession of three large calderas were formed, with the current caldera (Atitlan III) taking shape around 84,000 years ago. As time passed, three stratovolcanoes (San Pedro, Toliman, and Atitlan) erupted along the caldera's rim, and the majestic Lake Atitlan has filled in a large portion of the caldera. A truly breathtaking view of the lake, caldera, and surrounding volcanoes can be seen from the road between Solola and Panajachel (Figure 3).

Dozens of small Mayan towns line the banks of Lake Atitlan, including Santa Catarina, San Antonio, and Santiago de Atitlan as well as the tourist enclave of Panajachel. A regular speedboat service taxis local residents and visitors between the various lakeshore communities. A visit to the Panajachel market reveals that a sizeable Mennonite population has also settled in the Lake Atitlan area, taking advantage of the rich soils and abundant moisture.

The volcanic upland region of Guatemala is prone to seismic activity, however, most tremors go unnoticed. The "Earthquake Baroque" architecture style found in many of the highland towns became a regional adaptation to the episodic violent earthquakes. It is characterized by one-story buildings with thick stone walls, which have small, highplaced windows (Figure 4).

Although being located in the heart of a volcanic axis has its challenges, local Guatemalans are blessed with some of the

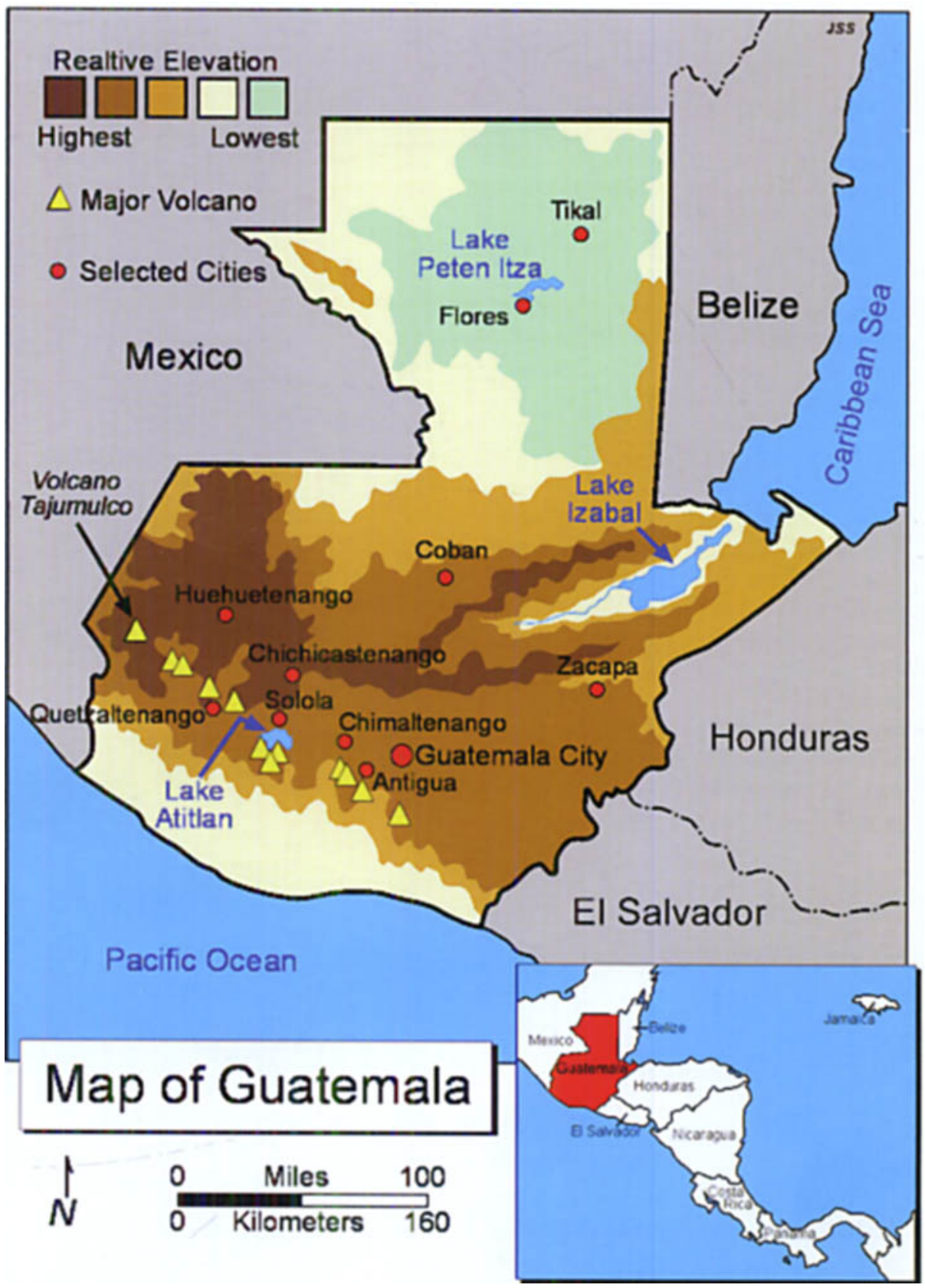

Figure 2: Map of Guatemala. Adapted from GraphicMaps.com. Cartography by author.

Figure 3: Lake Atitlan and volcanoes San Pedro and Toliman in background.

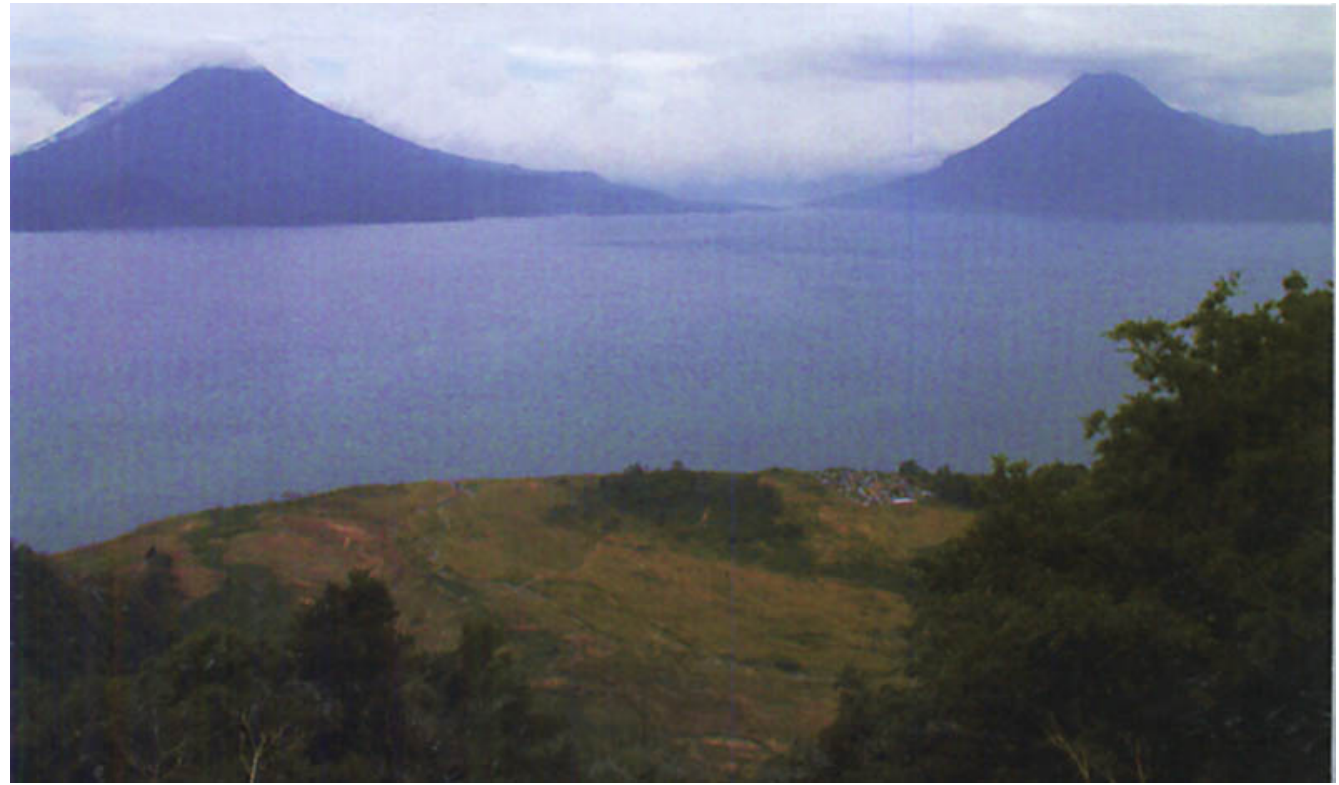


world's richest and most productive soils. Agricultural practices continue to provide the major source of livelihood and income for the country. According to the Central Intelligence Agency, in 2006 the formal agricultural sector accounted for one-fourth of the country's gross national product, two-thirds of its exports, and employed one-half of its 14.7 million citizens. This does not include the countless people in rural areas who toil and continue to engage in subsistence agriculture.

On one field trip, a local campesino (farmer) was seen hoeing his field (Figure 5). The volcanic soil he was working was so rich and soft that stepping through it felt like walking on pillows. The middle-aged campesino explained that he plants corn in March, removes weeds in May, plants beans in June, which use the cornstalks as a trellis, and harvests his crops between September and December. The fertility of Guatemala's highland, volcanic soil was most tellingly revealed when the farmer said that he has been raising corn and beans on the same plot of land for over 45 years and the only rest his land gets is between the months of December and March ${ }^{2}$.

Most of the land used for subsistence agriculture is on moderately to extremely steep slopes (Figure 6). Without the use of terraces or modern farm equipment, the local residents raise crops for personal consumption. By comparison, the flatter lands tend to be occupied more by agribusiness enterprises (Figure 7). Just outside the community of San Andres de Itzapa, are two

\footnotetext{
${ }^{2}$ Living in Guatemala's highland region with such deep volcanic topsoil has its drawbacks as well. In 2005, rains from Hurricane Stan inundated most of Guatemala's highland region, particularly around Lake Atitlan. Hill slopes gave way, and entire towns (especially Santiago de Atitlan) were covered in mud and debris. In some villages, the Guatemalan government suspended search efforts and declared them mass graves. Overall, an estimated 1,482 lives were lost.
}

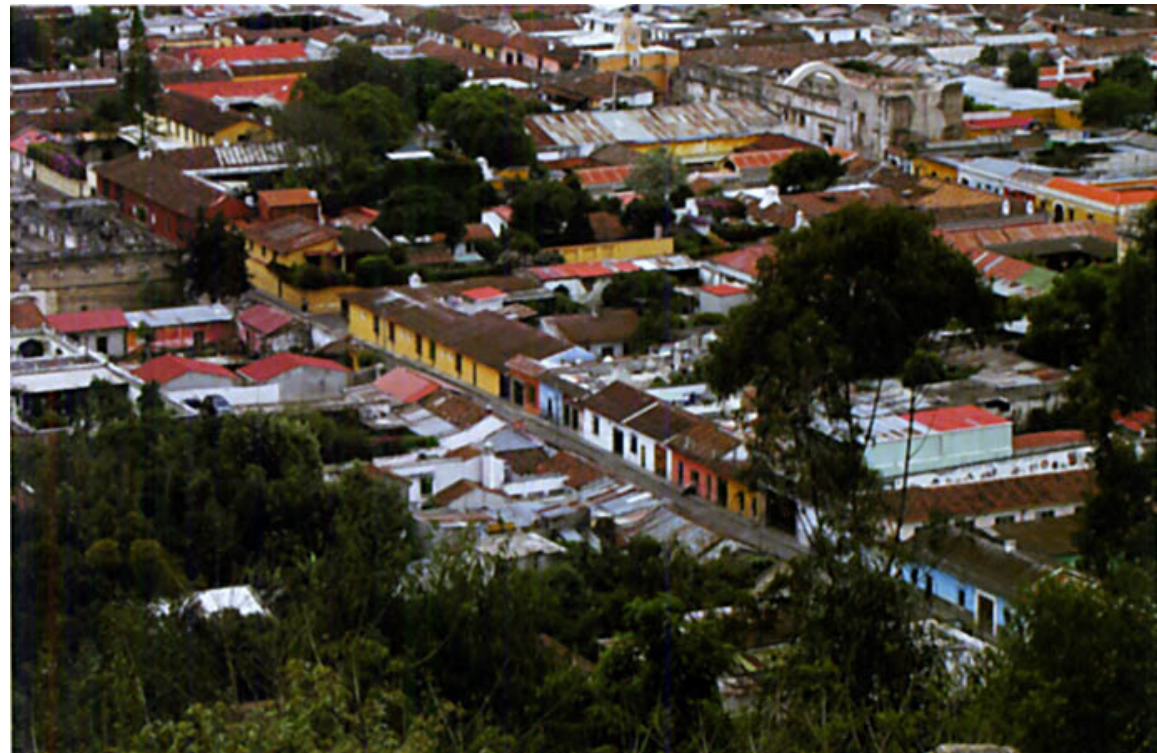

Figure 4: "Earthquake Baroque" architecture in Antigua, Guatemala.

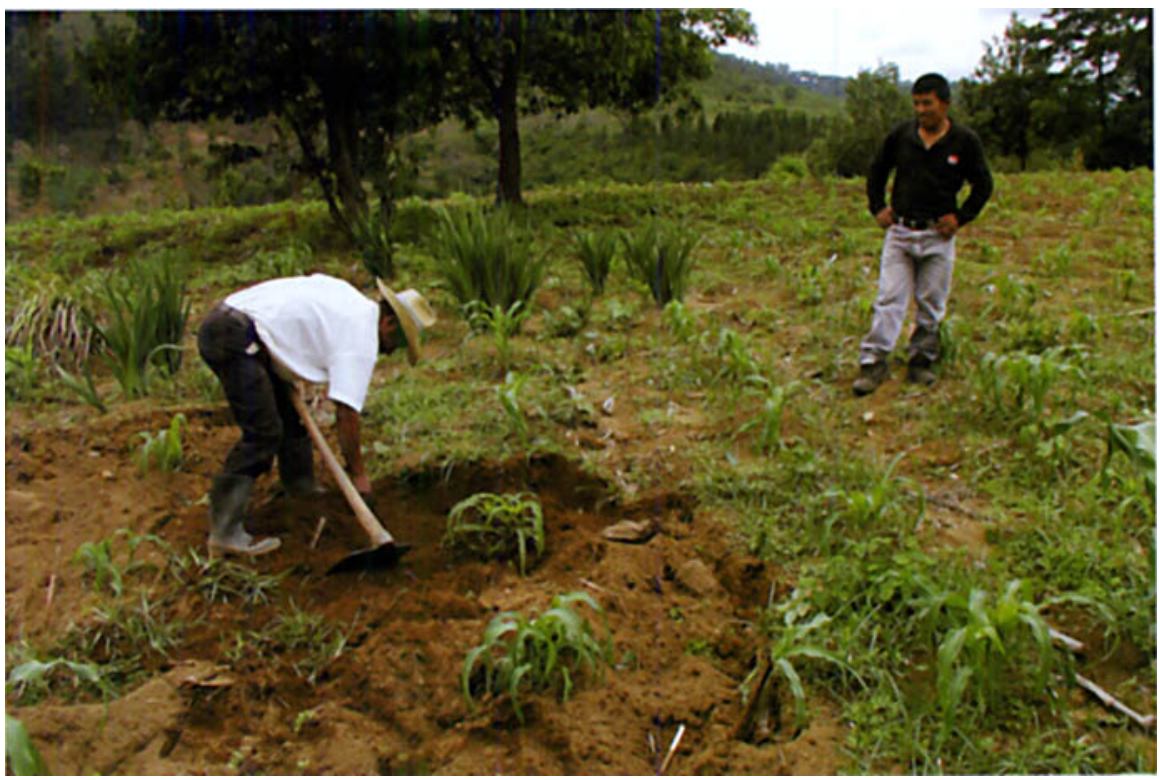

Figure 5: Campesino hoeing his cornfield growing out of the rich volcanic soils.

Figure 6: Corn growing on steep-sloped lands used by subsistence farmers.

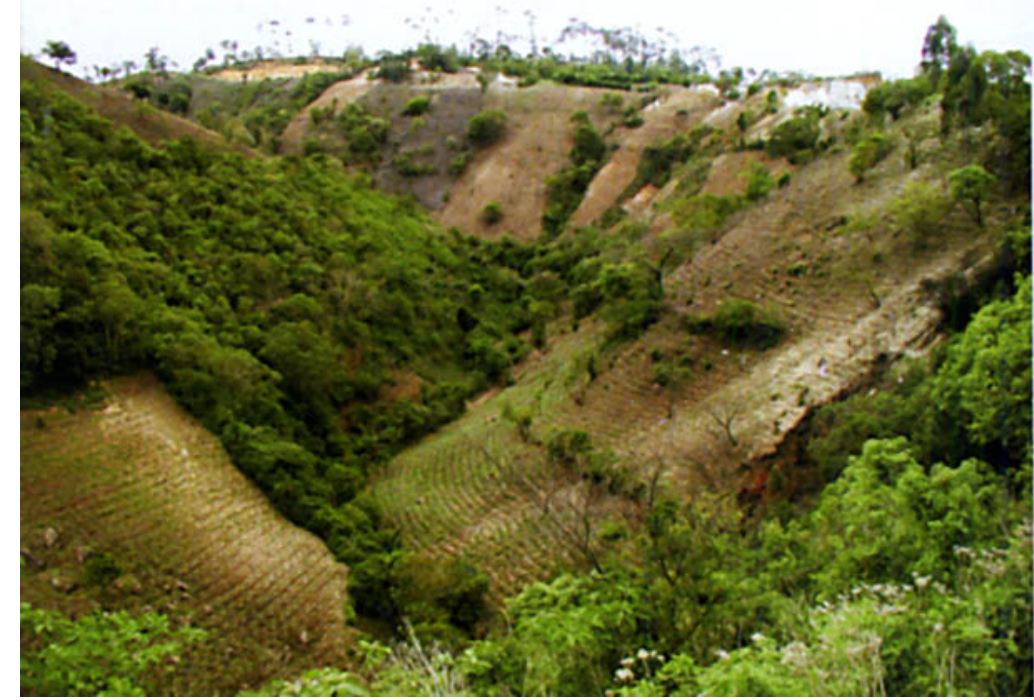

Figure 7: Modern agribusiness farm growing vegetables using drip irrization sustem.

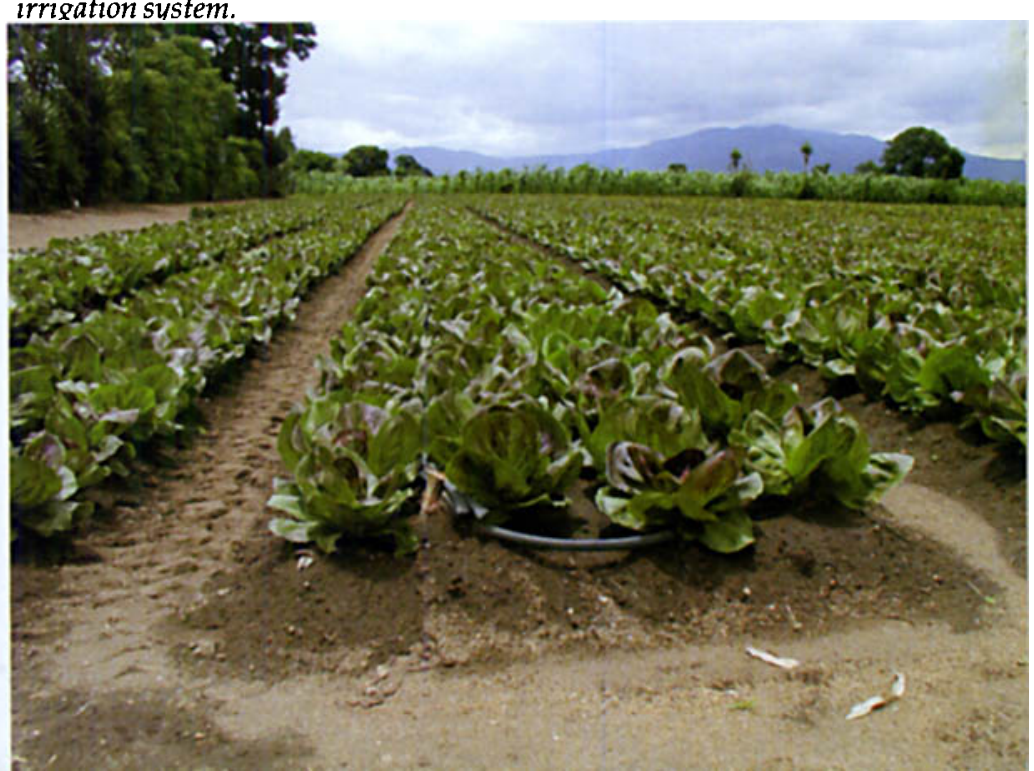



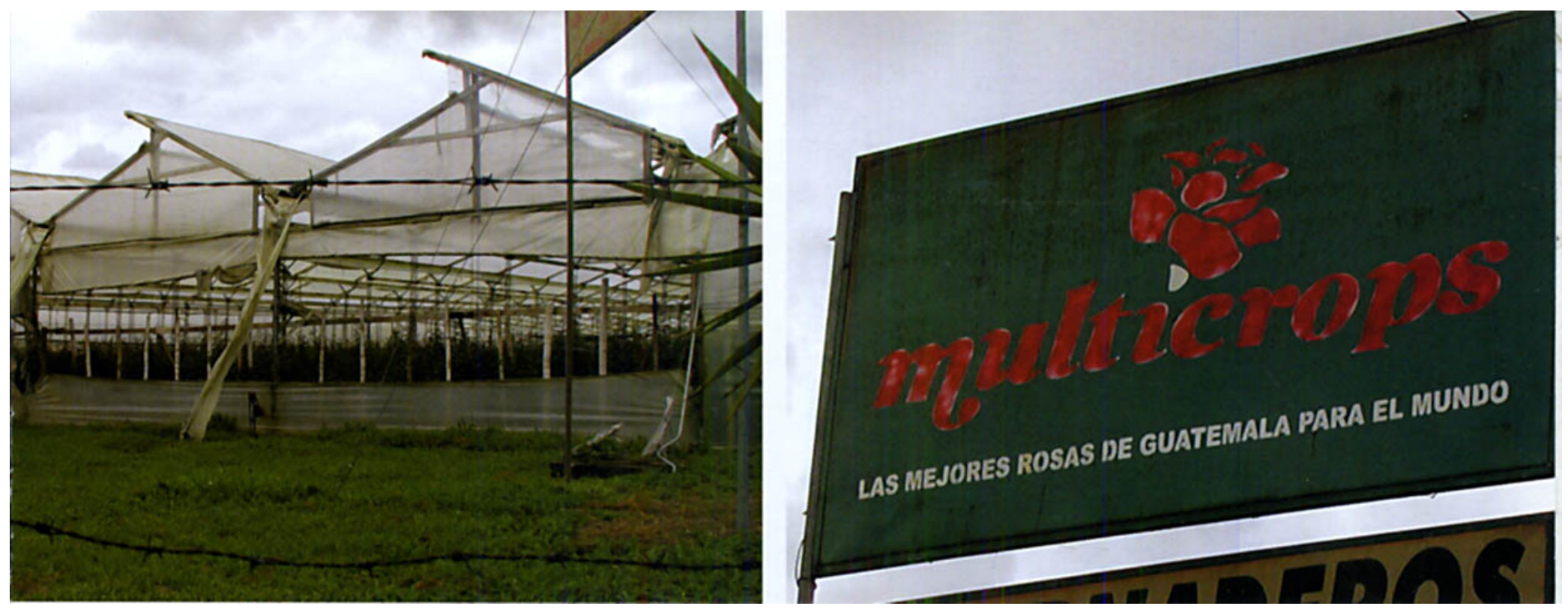

Figures 8 and 9: Modern greenhouse raising roses for the world market. The sign reads, "The best roses of Guatemala for the world."

examples of modern agricultural operations. One grows vegetables, including broccoli, cauliflower, and lettuce, for export to the world market. This operation utilizes the latest in modern farm equipment, including a drip irrigation system to deliver water to each plant. The other example is a state-of-the-art plantation which raises decorative flowers. Inside climate controlled greenhouses grow some of Guatemala's most prized roses (Figures 8 and 9).

In decades past, Guatemala was known throughout the world as a leading coffee exporting country, because its high elevation and rich volcanic soils produced some of the best-tasting beans. Over the past five years, however, Guatemala's coffee industry has seen some dramatic changes, and today coffee growers struggle to earn a living in the face of decreasing prices and increasing competition. In 2001, Brazil and Vietnam flooded the world coffee market with cheap, lower-quality beans, which drove prices to an eight-year low. Currently, the same two countries have cornered the market on supermarket grade coffee beans, and Guatemalan coffee farmers simply cannot afford to grow coffee anymore. They have found that the expense of fertilizer and hired labor exceeds their profits. To make matters worse, the price of coffee continues to drop. A Guatemalan coffee farmer takes home less than $\$ 0.45$ per pound, while the same coffee commands a price between $\$ 3.00$ and $\$ 6.00$ per pound in the United States. Many small-scale coffee farmers have decided to let the beans rot on the bushes, because at current prices, they cannot afford to hire pickers to harvest and process the beans (Figure 10).

Even Guatemala's larger coffee fincas (plantations) are feeling the pinch and are now scrambling to find a new niche to fill. Some, such as the Filadelfia Coffee Finca near Antigua, are promoting the uniqueness of their coffee in two different ways (Figure 11). They are trying to sway environmentally conscious consumers to purchase their coffee, because it is grown in a "bird friendly" environment shade trees protect the maturing beans from direct sunlight and provide a natural habitat for the birds. Secondly, they are marketing their coffee beans as organically grown, gourmet, pure Arabica coffee. Filadelfia Finca reminds its customers that coffee from pure Arabica beans is of premium quality and tastes much better than supermarket blends. Moreover, a number of coffee plantations are trying to diversify their operations. By offering hotel and firstclass resort accommodations with the finest quality restaurants, they are hoping to tap into Guatemala's rapidly expanding tourist industry. Small, family coffee growers, however, who lack the financial resources of Filadelfia Coffee Finca are left to grow subsistence crops because they can no longer afford to grow coffee.
Figure 10: Former small-scale coffee farms now growing subsistence crops on relatively steep slopes prone to soil erosion.

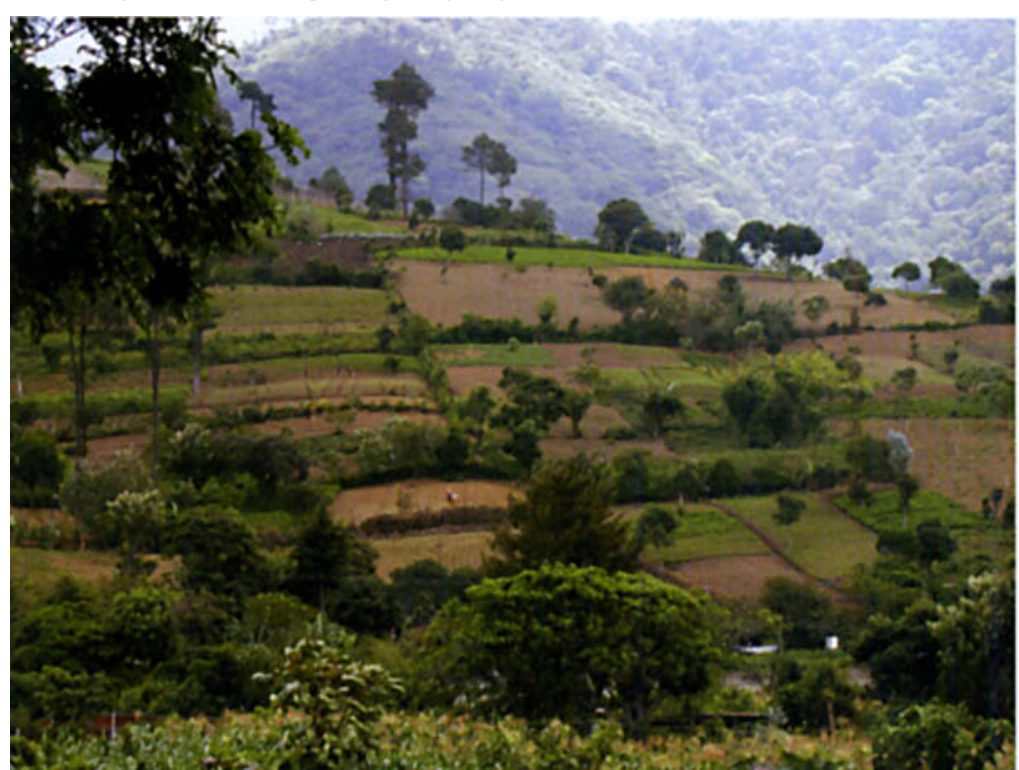

Figure 11: Sign at the Filadelfia Coffee Finca advertizing their premium quality Arabica beans and "bird friendly" plantation.

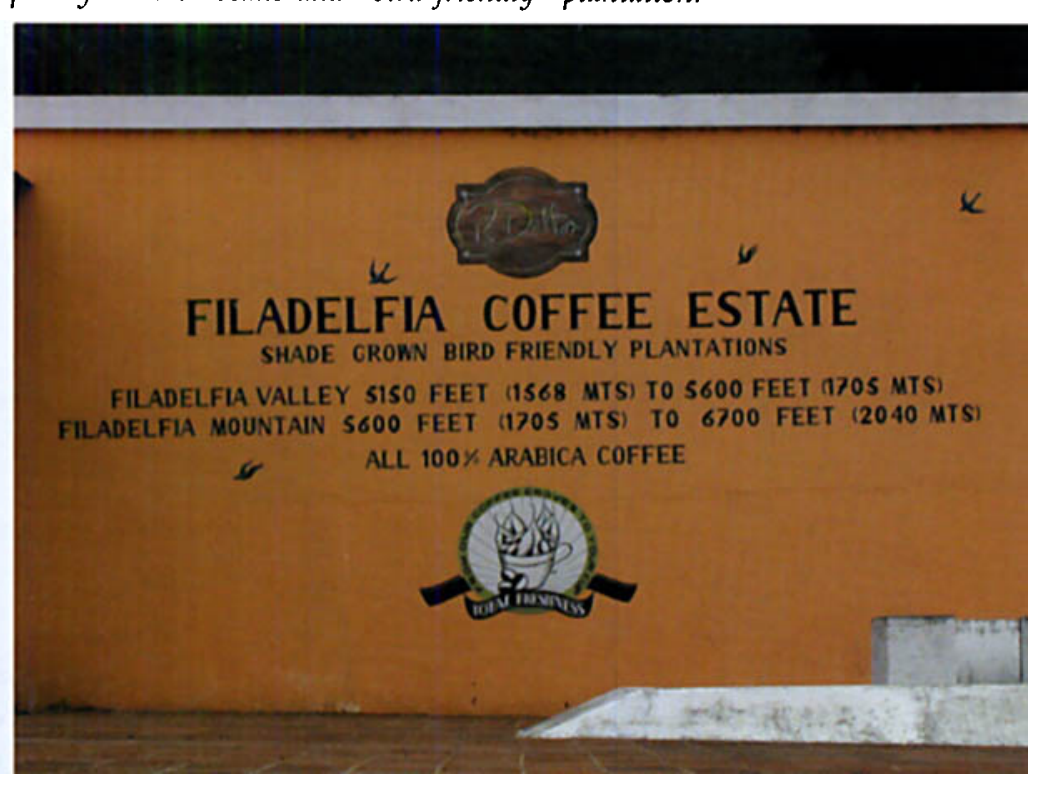




\section{Mayan Indians}

Demographically, Guatemala is fairly equally divided among principally two populations: Ladinos (people of mixed racial ancestry, mestizos) and Indians. Most accounts estimate Guatemala's Indian population comprises roughly $55 \%$ of the country's total population, making it one of the most indigenous countries in Latin America. Guatemala's two principle Indian groups are the Mayas and the Xinca. The Xinca Indians are a remnant population whose numbers have been dwindling dramatically over the past several decades. By far the Mayas comprise the largest indigenous population in Guatemala. Among the country's approximately 6 million Mayan people, there are at least 22 distinct ethnic dialects, including Quiche, Cakchiquel, Kekchi, and Ixil. The smallest and most commonly overlooked segment of Guatemalan society is the Garifuna, descendants of escaped African slaves who tend to live along Guatemala's Caribbean coast.

The majority of Guatemala's Mayan population lives in the heart of the highland corridor between Guatemala City and Quetzaltenango, but their presence is felt throughout the upland region (Figure 12). The names of many communities throughout the region reflect the strong Mayan influence as is evidenced by the suffix "tenango" of many Mayan towns which means "the place of." For example, the community named Jocotenango northwest of Antigua translates into English as "the place of the Joco bean," a bean eaten and used as an oil in cooking.

One of the most commonly identified and noteworthy aspects of Mayan material culture is their brightly colored textiles. Using a back strap loom, textiles are woven within each community and used for a variety of domestic and religious purposes. The most frequently seen textiles are the colorful traje (articles of clothing) worn by traditional Mayan men and women. It requires a trained eye to detect the subtle differences, but each community is known for its own design, and purportedly there are even subtle differences in motif along family lines within the same community. The designs represent various symbols of the community as well as local culture and family status. Women and men in brightly colored clothing can be seen at every turn of the head in the highlands region.

Globalization, however, is beginning to have an influence on the region. Workingage men in particular who have labored for a time in the United States are introducing changes in personal attire. Westernized young men no longer wear the traditional clothing but instead prefer oxford-type shirts and jeans (Figure 13). As has occurred among other Amerindian populations, I speculate that within ten years fewer and fewer males will wear the traditional Mayan traje.

Open-air markets are another aspect of

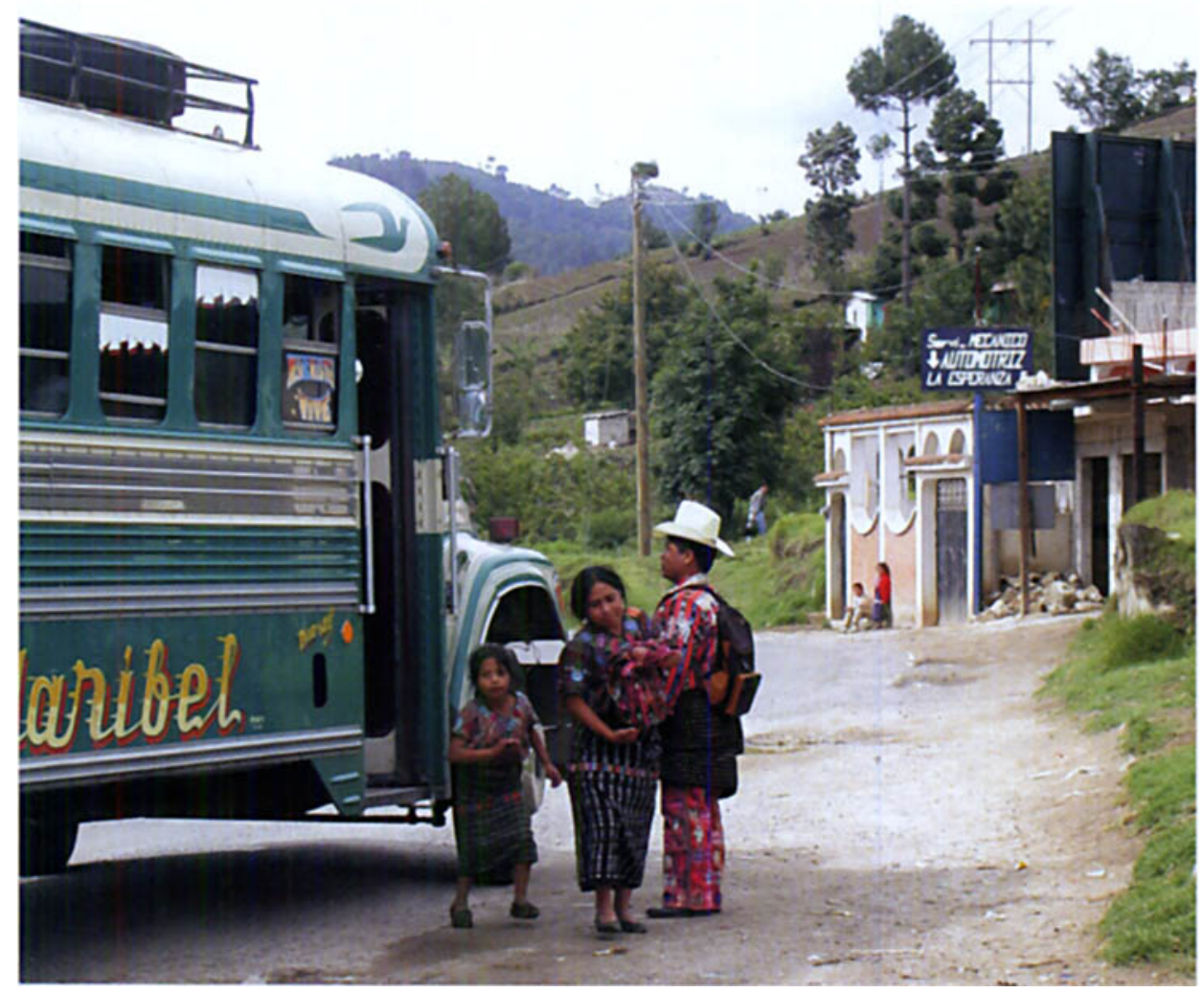

Figure 12: Mayan Indians in traditional dress at a bus stop near Solala, Guatemala.

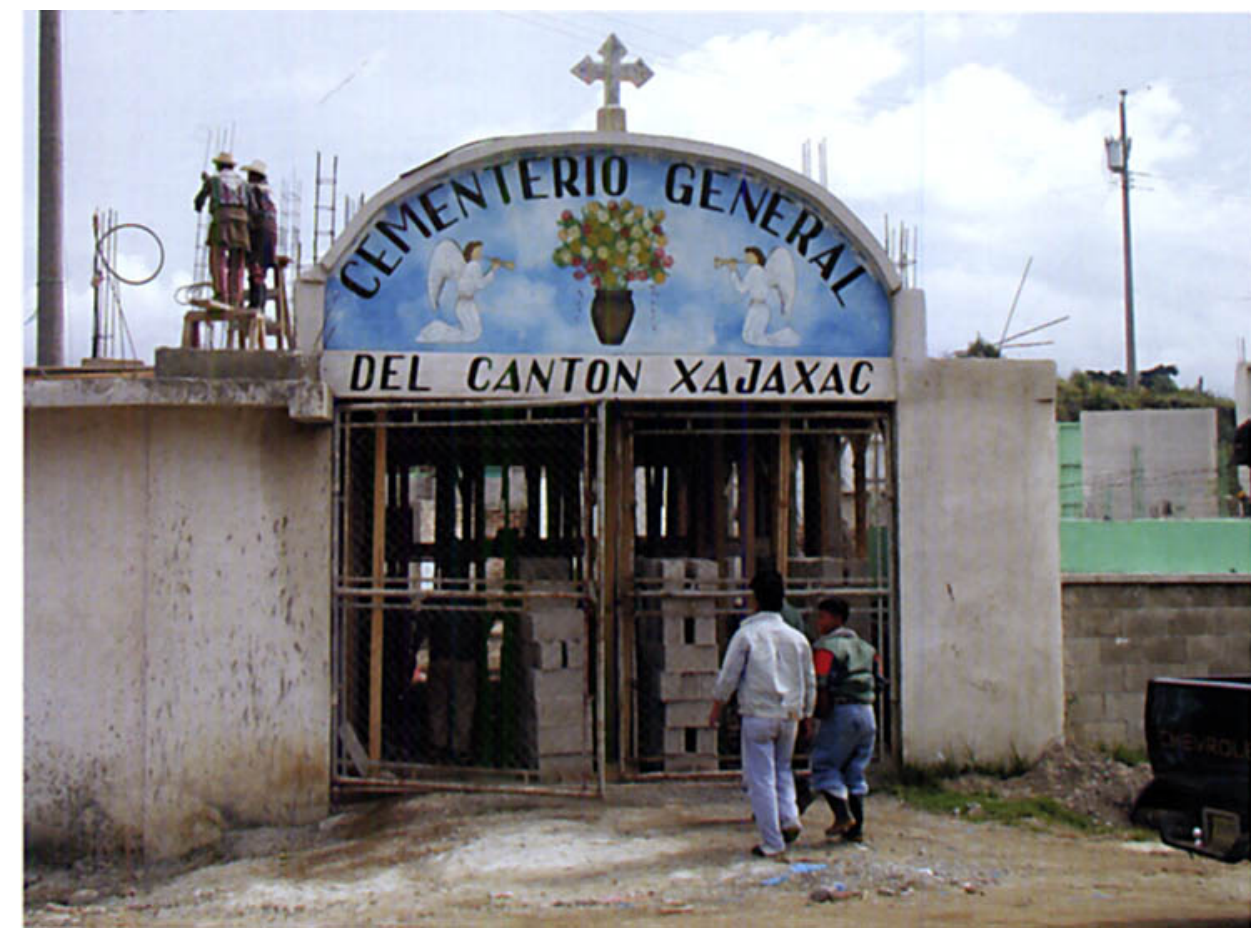

Figure 13: Traditionally dressed Mayan men working in a community cemetery with younger Mayan men dressed in "western" clothing at the entrance. 
traditional Mayan culture found in the highlands of Guatemala (Figure 14). Each community hosts a market at least one day a week, and the market in Chichicastenango is reported to be the most spectacular. A wide variety of merchandise is sold or bartered, but the most common items available are brightly colored textiles and freshly picked produce. The kaleidoscopic colors and bustling activities are truly remarkable and well worth the time and energy it takes to get to the remote villages.

One of the most interesting aspects of traditional Mayan culture centers around the religious beliefs of the folk saint named San Simon (more commonly referred to as Maximon pronounced Mashimon). Unfortunately, little research has been published on the religious beliefs surrounding San Simon, and, of the work that has reached print, more information is based on conjecture than fact.

Maximon is a curious blend of a traditional Mayan god, a Spanish conquistador, apostles Peter and Simon, archangel San Miguel, and Judas Iscariot. Most likenesses of San Simon feature an old man sitting in a simple wooden chair holding a staff in one hand and smoking a cigar (Figure 15). He is typically clad in a black suit and top hat with a black mask frequently covering his face. Even a quick glance shows why Maximon is considered the "dark saint" or the "patron saint of sinners."

The origins of Maximon predate Spanish arrival. The Pre-Columbian god Maam (meaning "grandfather" or "ancient one") was a powerful deity of the Mayan underworld. Maam was deeply revered for his healing powers and the miracles he performed. The poorest of the Mayan poor would call upon Maam to intercede in the most impossible of situations, and it is said that he rarely left their prayers unanswered.

The colonial Catholic Church tried to incorporate Maam, as well as other Mayan deities, into their communion of saints. In the case of Maam, the Catholic Church was so concerned about his strong following that they decided to discredit him by aligning him with Judas Iscariot (the patron saint of traitors). The Church hoped that by focusing on his betrayal qualities, the Mayan population would abandon their worship of him. Instead, the Mayan Indians revered San Simon even more because he resembled a Catholic Robin Hood steeling from the rich and giving to the poor. In contrast to the perspectives of the Catholic Church, the Mayan religion believes that the world is comprised of both positive and negative energies, and the dark side of Maximon appealed to their understanding that from darkness comes light and a new day.

Maximon has become Guatemala's most popular saint and most revered religious icon. He is closely associated with miracles and lost causes. Today, people petition for Maximon's assistance in curing diseases, blessing crops, removing curses, winning lawsuits, and divining for the future. Maximon has also become known as the saint whose powers are most effective in dealing with disputes with a Ladino or with the government. His popularity became most pronounced in the highland villages around Lake Atitlan, especially in his home community of Santiago de Atitlan. It is reported that because of Maximon's power and influence among the local Mayan Indians, some of the bloodiest battles during the Guatemalan civil war

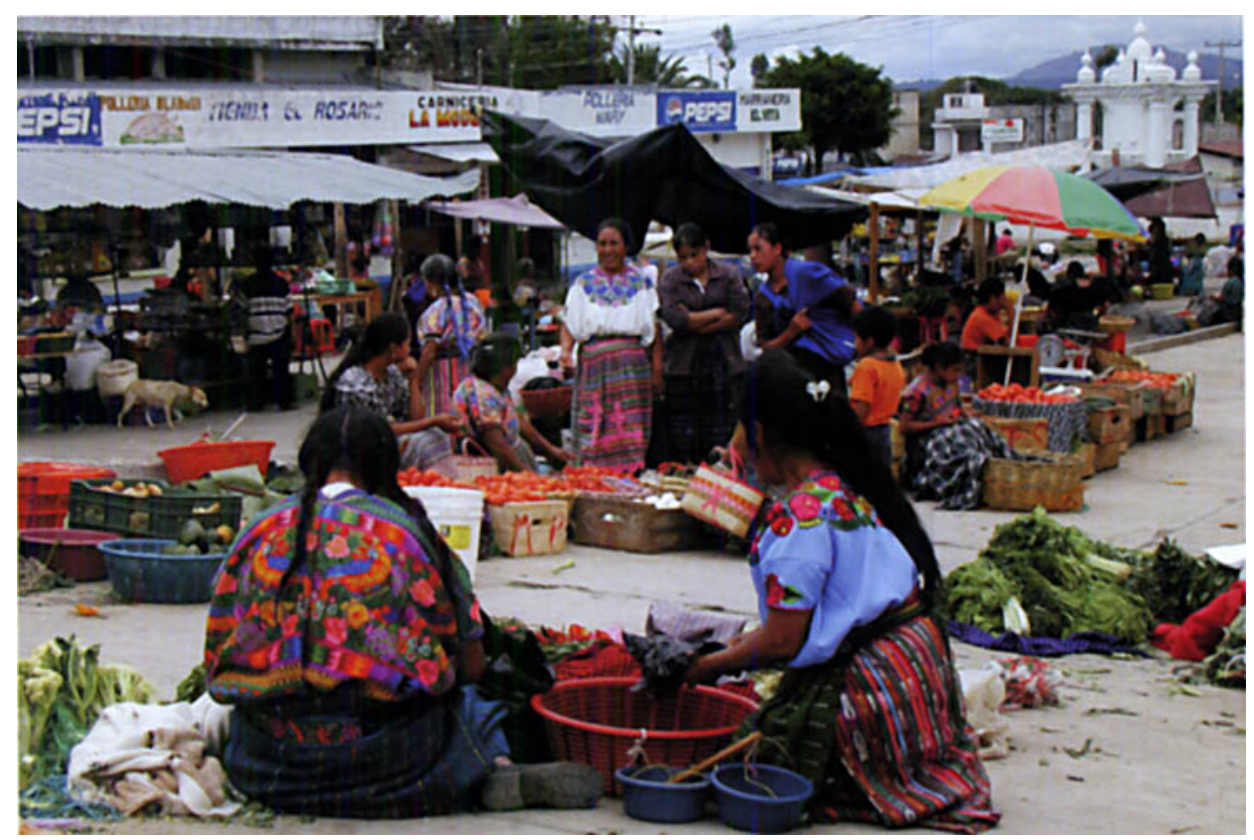

Figure 14: Open-air market in San Andres de Itzapa with Mayan women wearing traditional traje.

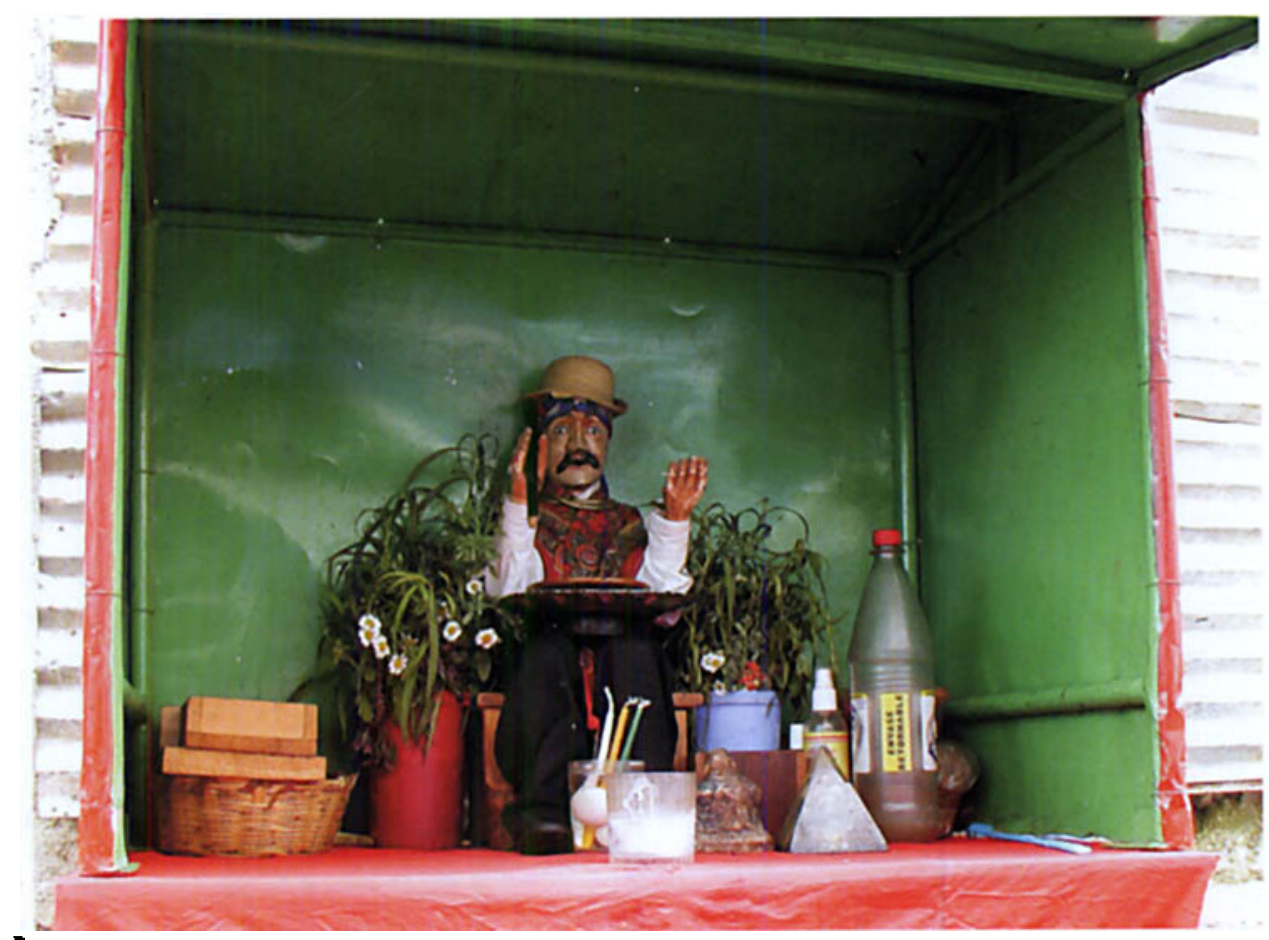

Figure 15: Statue of San Simon in a small shrine outside the Chapel of San Simon in San Andres De Itzapa, Guatemala. 


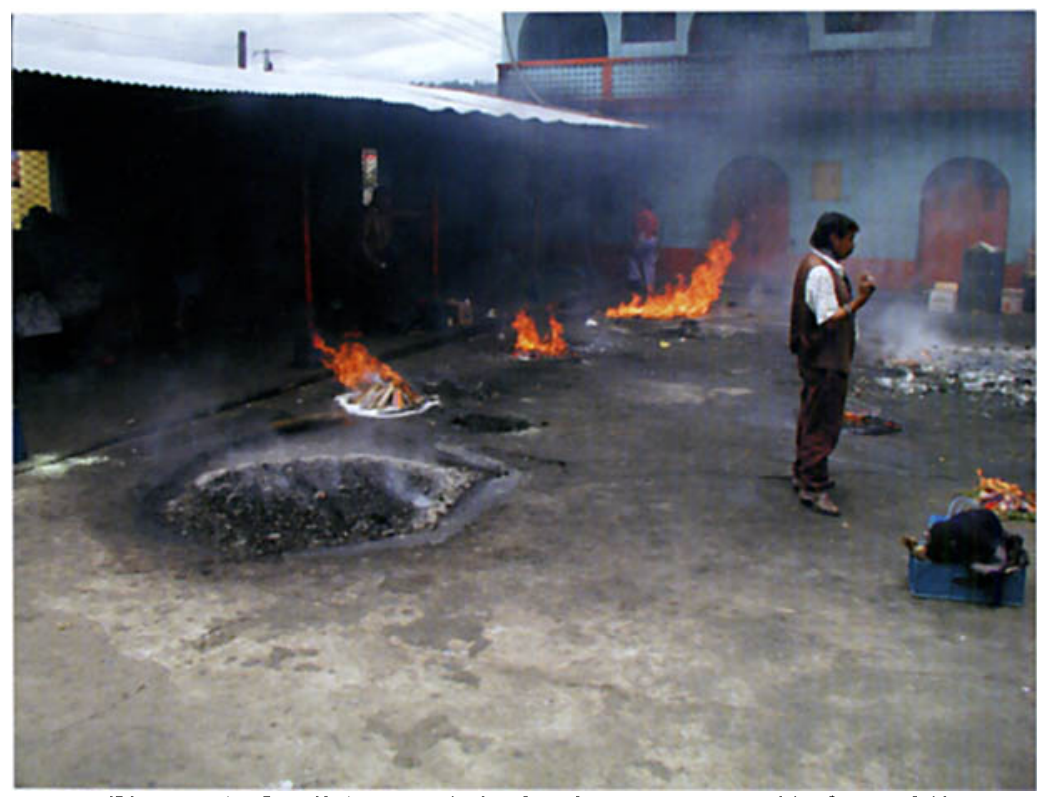

Figure 16: Small, incense-laden bonfires in courtyard in front of Chapel of San Simon. Bonfires are used to cleanse the body and soul by waving hands through smoke.

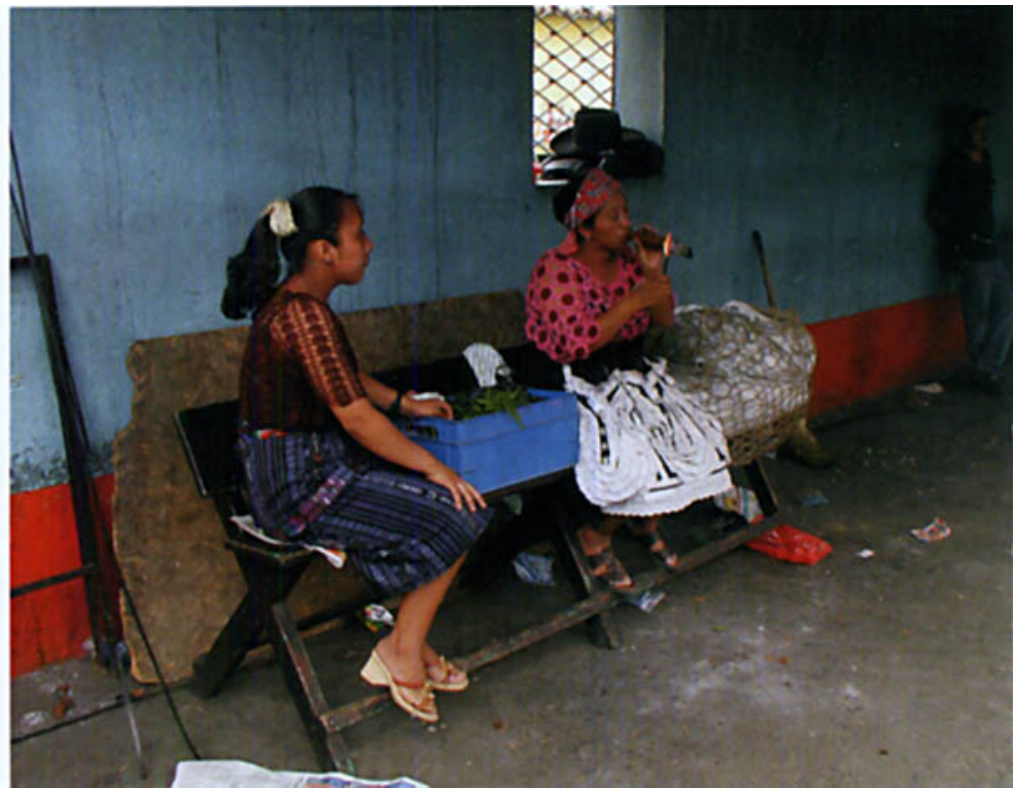

Figure 17: Older Mayan woman smoking a cigar in courtyard outside Chapel of San Simon in San Andres de Itzapa, Guatemala. were fought in the highland region around Lake Atitlan. Other villages where chapels have been built in honor of Maximon include Zunil, San Lucas, Patzun, Nahuala, and San Andres de Itzapa. A visit to the Chapel of San Simon in San Andres de Itzapa is truly an eye-opening experience.

After leaving the paved road and riding up a steep, bone-jarring, potholed road, one arrives at the entrance to the Chapel of San Simon. In the courtyard, worshipers use the smoke from small, incense-laden bonfires to cleanse their body and soul (Figure 16). Working their way around the fire in a small circle, they chant prayers and flush their blood into their fingers. Then they wave their hands through the smoke and over the fire to cleanse the blood in their fingertips. Around the edge of the courtyard, other worshipers smoke gigantic puras (cigars eight to ten inches long and about three inches in diameter). I witnessed an older woman who was smoking her cigar as rapidly as possible so as to induce hallucinations (Figure 17). After performing the first of the cleansing procedures, worshipers enter the chapel.

Surprisingly, the chapel contains no pews or benches upon which to sit and pray as one would expect to find in a Catholic church. Instead, the smoke-filled room has a series of metal tables with burning candles, pools of wax, and bottles of hard alcohol sitting on them (Figure 18). In the center of the sanctuary, people quietly chant prayers petitioning Maximon for his assistance. Along the east wall, a line of people wait patiently for their turn to step up to the altar.

On the altar, a Curandera (shaman/faith healer) individually blesses and cleanses those who have waited in line.
She begins by saying a chant over the person's body while simultaneously slapping and brushing the person's body with a handful of leafy branches. She finishes the cleansing process by taking a drink of grain alcohol and spraying it from her mouth all over the person's body (Figure 19). After receiving the cleansing, the worshiper places their monetary offering on the lap of the full-sized statue of Maximon. The Curandera neither accepts nor handles the money but instead instructs people where to place their offering. The fee for the Curandera's mediating services runs about 600 Quetzales (about $\$ 70$ to $\$ 80$ US), which is a considerable sum given the fact that $60 \%$ of all Guatemalans earn less than $\$ 2$ US a day. Attached to the walls of the chapel are small metal plaques giving thanks to San Simon for his help in a miracle or during a difficult time in the person's life.
Figure 18: Inside the Chapel of San Simon in San Andres de Itzapa, Guatemala. Metal tables hold candles and bottles of hard alcohol as worshipers chant or wait to proceed to the altar.

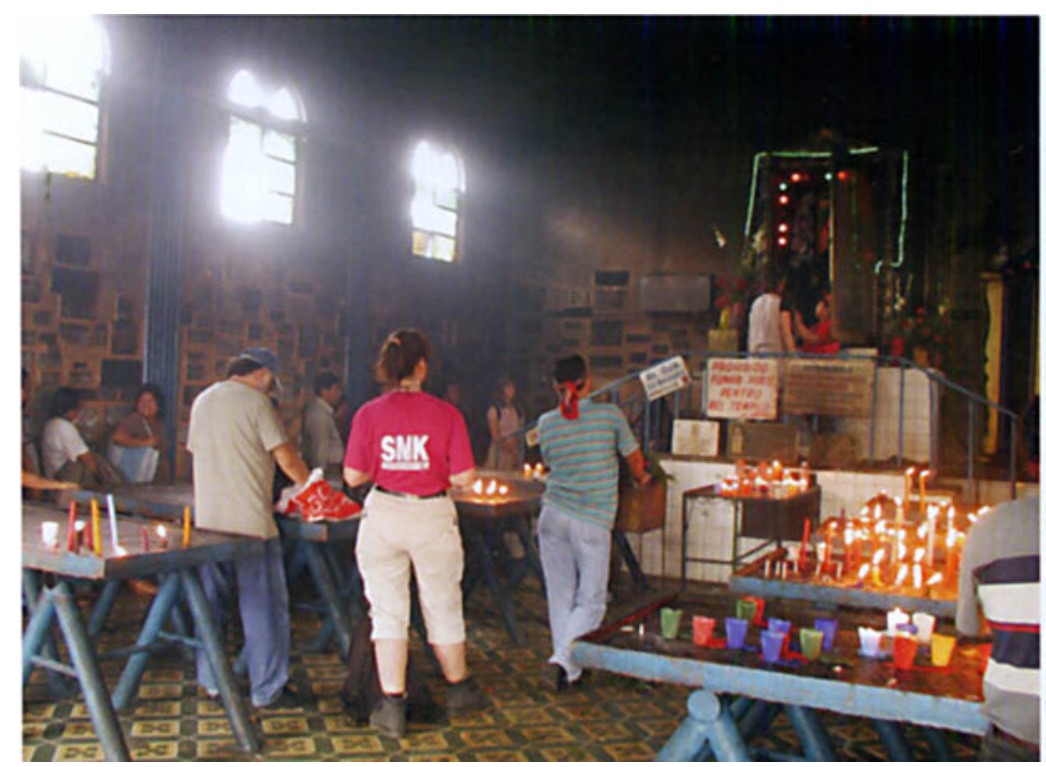

Figure 19: Altar inside Chapel of San Simon in San Andres de Itzapa, Guatemala. A Curandera cleanses a worshiper by spraying him with alcohol from her mouth. A statue of Maximon sits in a wooden chair with a painting of Our Lady of Guadalupe behind him.

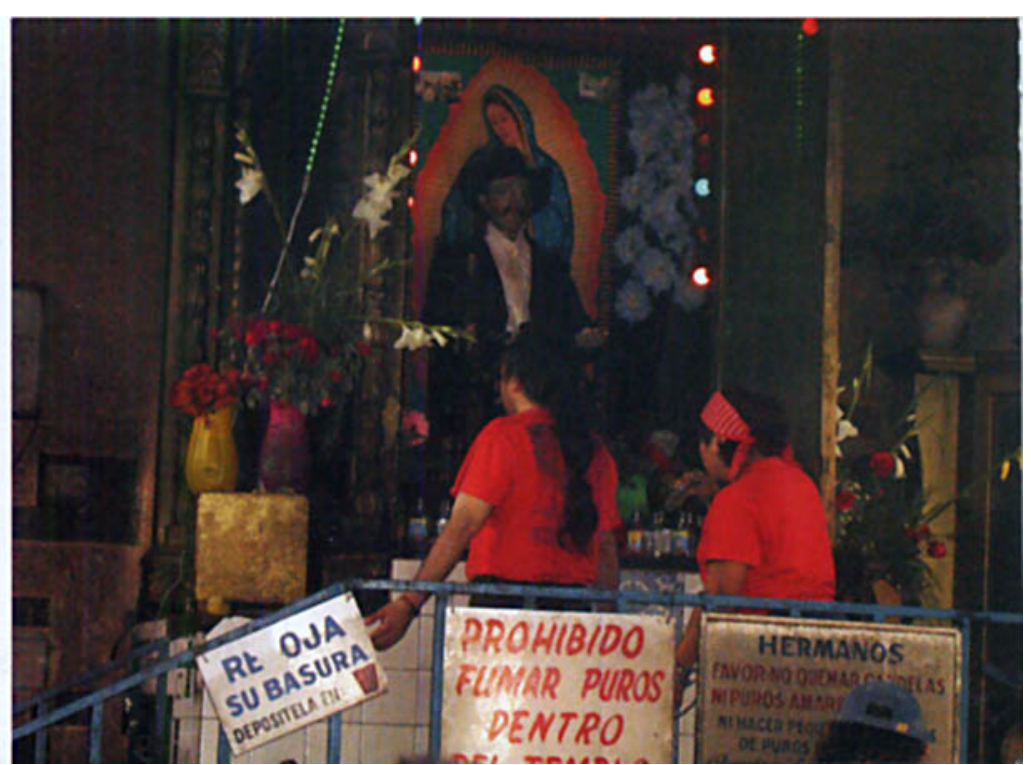


Inside and outside the chapel, the Catholic Church has posted numerous signs, including nameplates, public information, and hours the structure is open (7:00am to $5: 00 \mathrm{pm}$ daily). The presence of these markers provides ample evidence that the activities in the chapel are officially sanctioned by the Church. Furthermore, on the altar there is an interesting juxtaposition of traditional Mayan and Catholic icons. Sitting in his chair is Maximon, but prominently displayed on the wall behind him is a picture of Our Lady of Guadalupe (Figure 19). The entire scene is a classic example of Mayan-Catholic fusion. It is also an excellent reminder of how religious syncretism was used by the Catholic Church as a tool to help convert the Amerindians to Catholicism. Today, Maximon is the most popular saint in Guatemala, but his appeal has spread throughout southern Mexico and the rest of Central America.

Guatemala has one of the greatest disparities in income and land ownership in Latin America. According to an article that appeared in the May 17, 2003 issue of The Economist, a scant $3 \%$ of Guatemala's population owns over $65 \%$ of the land, and $10 \%$ of all Guatemalans earn $47 \%$ of the household income. Moreover, $90 \%$ of Guatemala's Indian population lives in "poverty" (the U.N. defines poverty as earning less than $\$ 2 /$ day), and nearly $70 \%$ of the Indians live in "abject poverty" (defined as earning less than $\$ 1 /$ day). Resulting from this pronounced poverty, many families, especially Mayan, do not have the financial resources to care for their children. Guatemala has become known as one of the leading adoption-sending countries in the world, and the main source of intercountry adoption is through birth parent relinquishment (Figure 20). According to Bethany Christian Services (an

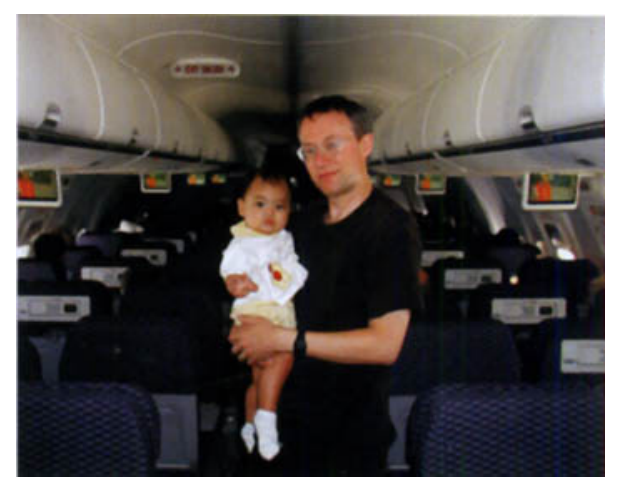

Figure 20: An unidentified man with his newly adopted Guatemalan baby girl flying back to the U.S. after completing the adoption procedure. international adoption agency based in Grand Rapids, Michigan), leading destinations for adopted Guatemalan children are the United States, Canada, Western Europe, and Australia. In 1998, over 900 children were adopted by U.S.based parents, and by 2002 , that number had increased to 2,300 children. As adoptions have become increasingly difficult in other parts of the world, the appeal of adopting Guatemalan children is increasing. A growing challenge which the Guatemalan government faces is that some children from rural Guatemala and southern Mexico are being abducted from their families and offered up for adoption as a profit scheme by unlawful organizations. The Guatemalan government has responded by making the adoptive process much more tightly regulated. The fact remains that more than 2000 Guatemalan children (mostly Mayan Indian) are put up for foreign adoption every year, with about $55 \%$ of them going to families in the U.S. and Canada.

The rugged terrain of Guatemala's highland region has allowed generations of Mayan Indians to live in isolation. As a result, rich cultural traditions, including dress and religious practices, rooted in the past have continued to flourish. Unfortunately, the same geographic isolation has prevented many of the Mayan Indians from escaping the bonds of abject poverty.

\section{Civil War}

During the Cold War (1945 - ca. 1991), many Central American countries experienced prolonged periods of civil unrest as U.S.- and Soviet-backed military groups vied for control. In Guatemala, what began as yet another theater of fighting turned into a struggle over land reform and a push for Indian rights and equality. Guatemala's civil war officially ended in 1996, yet the wounds are still fresh in people's minds, especially in the country's highland communities.

Guatemala's civil war started in 1954 soon after Jacobo Arbenz was elected President and began implementing various agrarian land reforms. Many adversely affected U.S. business interests, especially those of the United Fruit Company. To prevent the continued erosion of U.S. profits, local rebels backed by the CIA staged a successful coup that ushered in 30 years of military-controlled governance. By the early 1970s, numerous guerrilla groups in the highlands formed to oppose growing military brutality. In 1982, General Efrain Rios Montt seized power and began one of the bloodiest episodes of the civil war. During his reign as dictator, thousands of people (mostly Mayan Indian) were killed, and more than 400 villages were wiped off the map, including the infamous town of Dos Erres. There, a handful of villagers survived the complete extermination of their friends and family by hiding in the woods. General Rios Montt was removed from power in 1983 during the country's last successful coup. In 1985, Vinicio Cerezo won the Presidency in a national election, and six years later, Jorge Serrano assumed the post in the first peaceful transition of power since World War II. The war against the insurgents and their Indian supporters, however, was far from over. In 1992, Rigoberta Menchu was awarded the Nobel Peace Prize for her efforts at bringing all sides to the bargaining table and resuming peace talks. Four long years later, a treaty was finally signed by both the government and the Indian people. The 1996 Peace Accord called for greater representation of the Indigenous communities, a scaled back military and police force within the country, and the establishment of a land bank that would arbitrate land disputes.

In the 36 years of fighting, 200,000 people were left dead, another 200,000 refugees fled to nearby countries, especially Mexico, 45,000 people disappeared, and the lives of over one million people were uprooted. Although the war ravaged nearly every corner of Guatemalan soil, the fiercest fighting occurred in the Mayandominated villages of the western highlands in the corridor between Chimaltenango and Huehuetenango. As Michael Steinberg et al. reported in 2005, there is a clear correlation between massacre sites and departments (states) with a high percentage of Mayan Indians. Throughout the war, the government identified "Red Zones" as areas where no distinction could be made between the guerrilla fighters and their Mayan Indian supporters. The fighting officially ended in 1996, yet repercussions from the intense fighting are still evident today, and the western Highlands remains a deeply troubled area ravaged by the war.

In their 2003 Geographical Review article, Michael Steinberg and Matthew Taylor asserted that, especially in the country's rural highlands, Guatemala's civil war still smolders and is far from resolved. "The tenuous fabric of peace has been stretched to the maximum as politically motivated 
murders, land conflicts, and mob lynching continue." (Steinberg and Taylor, 2003: p.453)

During the height of the civil war, it was common to see unmarked military trucks with men in masks driving through rural villages. Government-backed hit squads commonly called "White Warriors" combed the highland villages and killed anyone believed to oppose the government while simultaneously shanghaiing young men as new recruits. With the civil war over, one would no longer expect to see such sights. Yet, during a field trip between Antigua and Lake Atitlan, I witnessed three unmarked military trucks filled with masked men carrying high-powered, automatic weapons (Figure 21). Local residents (especially middle-aged women) stared in horror as the trucks passed through their villages, providing a glimpse at how terrified the local Indians must have felt during the war.

While on another field trip, I encountered an older man grazing his livestock alongside the road. After a conversation with the unidentified man, I asked him if I could take his picture. He agreed, but immediately dropped his head and held forth his machete (Figure 22). I invited him to lift his face to the camera, but he declined. After the camera was put away, he explained that he did not want a photo of his face taken, because he was afraid it might end up on a governmental hit list. It is evident that the wounds left by the war are still raw.

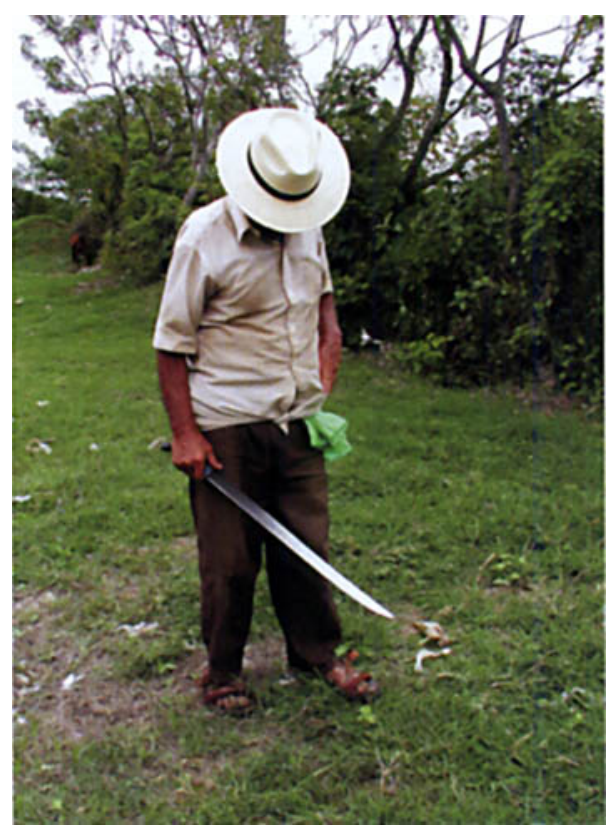

Figure 22: An older Mayan man willing to have his photo taken but uncomfortable having his face captured.

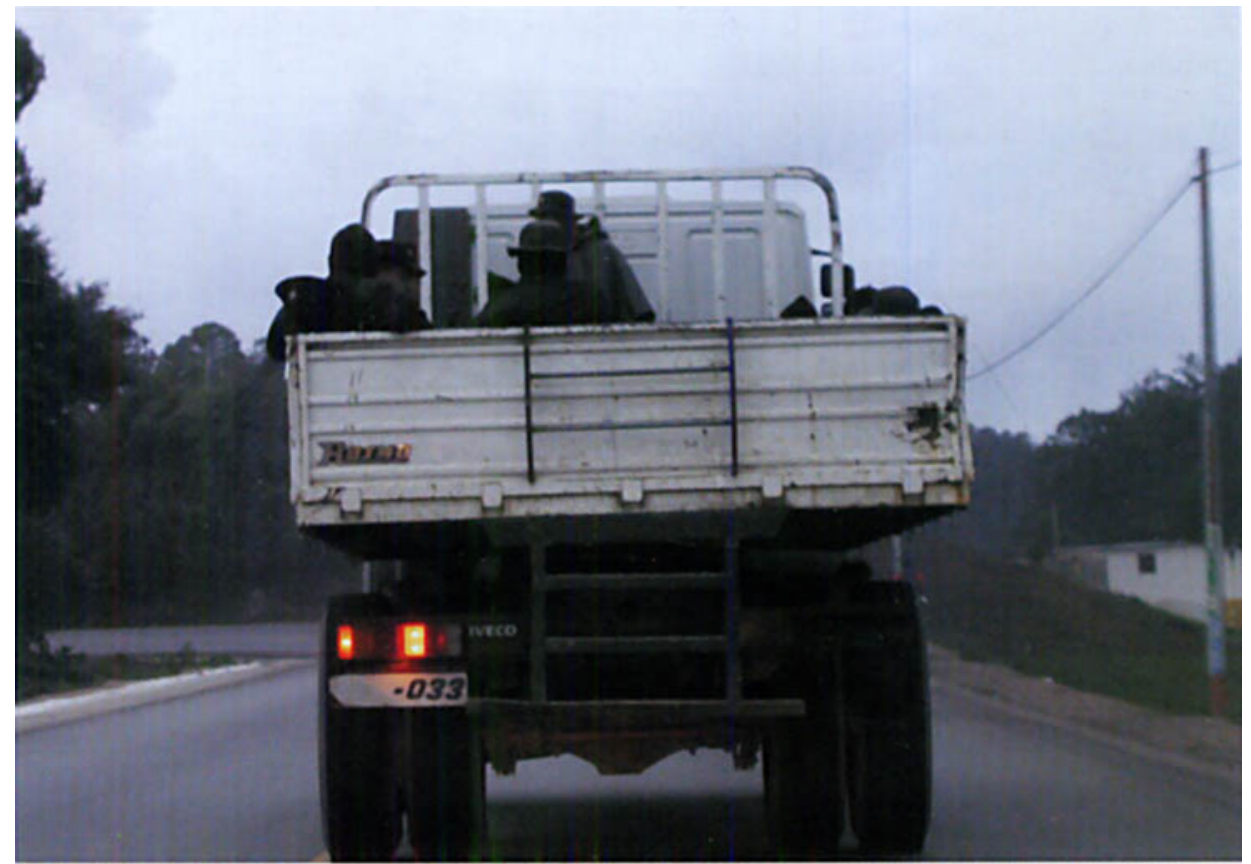

Figure 21: An unmarked military truck with masked men on the road between Antigua and Lake Atitlan in the highlands of Guatemala.

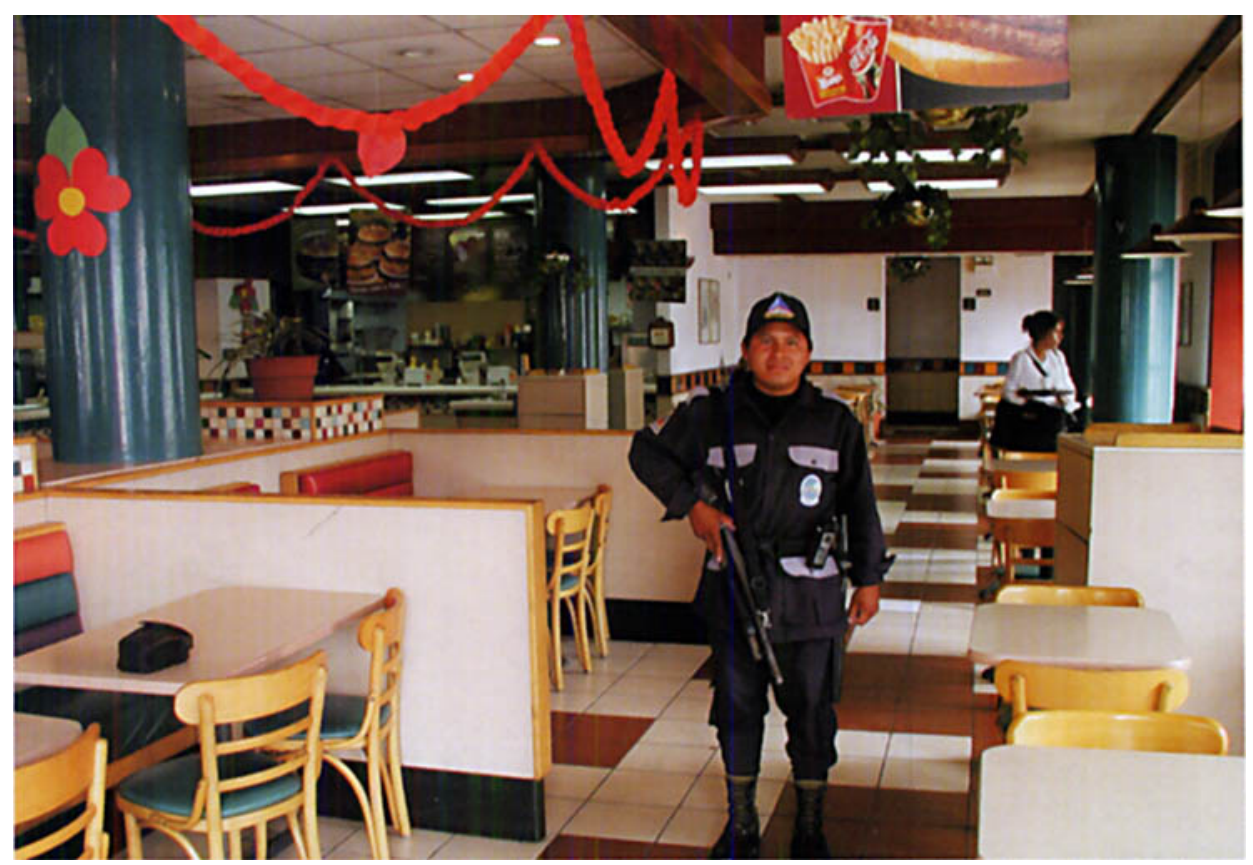

Figure 23: A young man serving as guard in a Wendy's Restaurant in Guatemala City.

Another common Guatemalan scene that was unexpected was the prevalence of heavily-armed guards in front of banks and key businesses. The guards ranged in age from their late teens to their late $50 \mathrm{~s}$, and they all stood sentry carrying an automatic weapon. Even at the Wendy's restaurant just off the main Plaza in Guatemala City, a young man guarded the establishment with a high-powered rifle (Figure 23). Later, I was informed that only a handful of their guns are loaded, but their presence clearly deters crime and civil unrest.

As in most Latin American cities, the main plaza in Guatemala City is dominated by government buildings and the main Catholic cathedral. Evidence of the civil war's impact on Guatemalan society is especially evident on the pillars that ring the cathedral's front entrance (Figure 24). Within the last five years, the Guatemalan Catholic Church has engraved the names of all people known to have been massacred, assassinated, and abducted or are still 


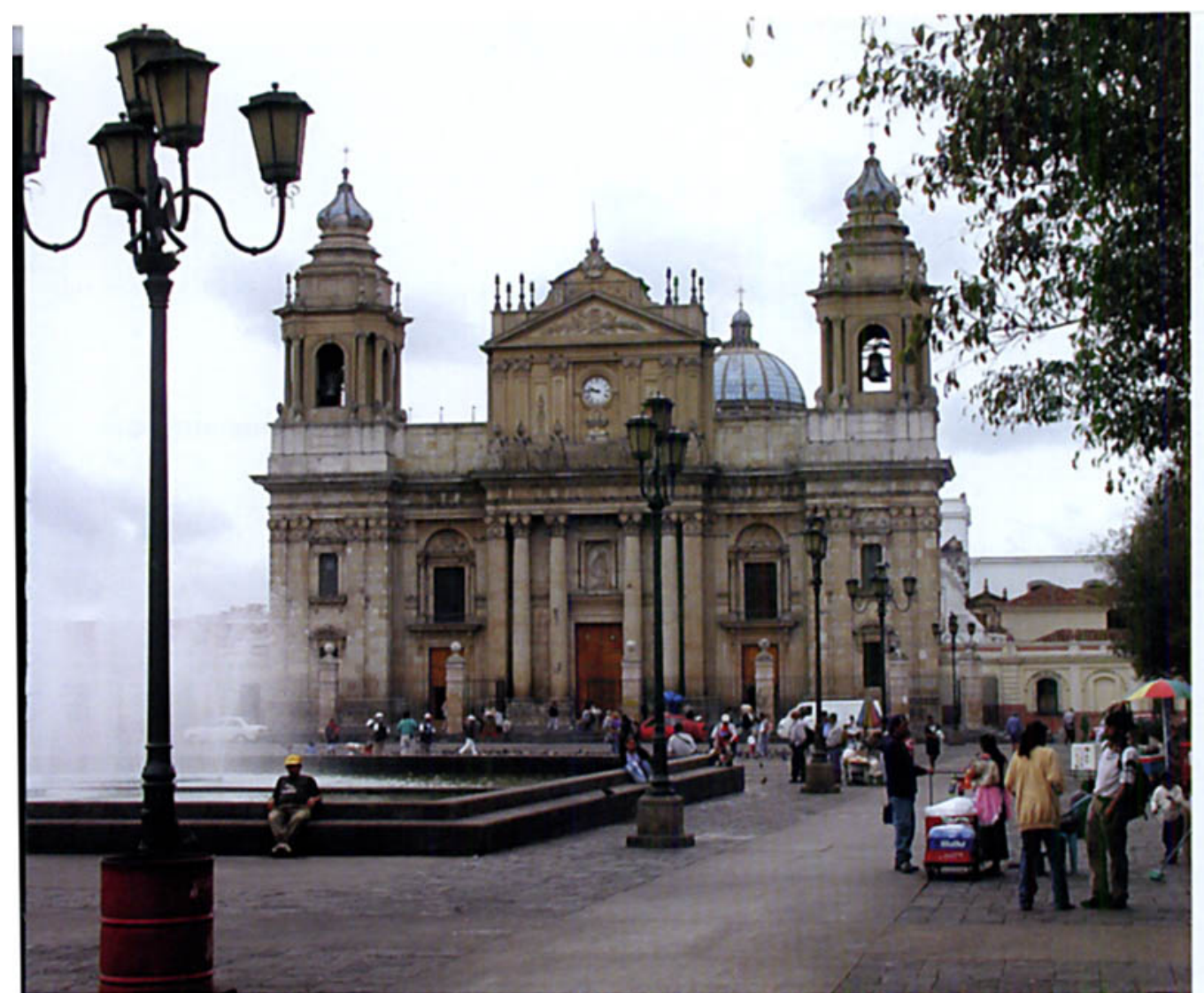

(A)

Figure 24: (A) A view of the main Catholic Cathedral in the central plaza in Guatemala City. (B) A photo of the pillars that line the cathedral's courtyard. (C) Some of the names of the victims of the 36-year civil war in Guatemala have been engraved on the pillars by the Church.

missing. The lists of names are as long as the pillars are high, and new names are continually being added as more information comes to light. As Steinberg and Taylor note, the Catholic Church has been one of the most outspoken voices against governmental oppression, and these pillars speak volumes for the victims. Maybe by posting the names, the Catholic Church is bringing closure to the war and helping to begin the healing process.

Given the Catholic Church's strong opposition to the military-run government and its outspoken support of the guerrilla insurgents, during the war one of the best ways for Guatemalans to avoid being a target of governmental death squads was to become Protestant. In the eyes of the military government, becoming Protestant meant that you embraced western ideals and supported the existing power structure within the country. Today, Guatemala has one of the highest percentages of Protestant populations within Latin America, and, as reported by Steinberg and Taylor, Guatemala is projected to become the first Latin American country with a Protestant majority. Driving through the rural highlands one sees numerous Protestant churches of all denominations from Baptist to the Church of Jesus Christ of Latter-day Saints (Mormons) (Figure 25). Given the historical dominance and overwhelming influence of the Catholic Church, the abundance of Protestant churches seen in the highlands of Guatemala is amazing.

\section{Conclusion}

Guatemala is a truly wonderful country with a wealth of cultural attractions and spectacular scenery. And, as peace returns to this Central American country, more and more tourists will seek to witness the unique, if not bewildering, qualities of the Mayan culture. As the country becomes inundated with foreign tourists, the Mayan culture within Guatemala's highland villages will change as local residents increasingly embrace western cultural

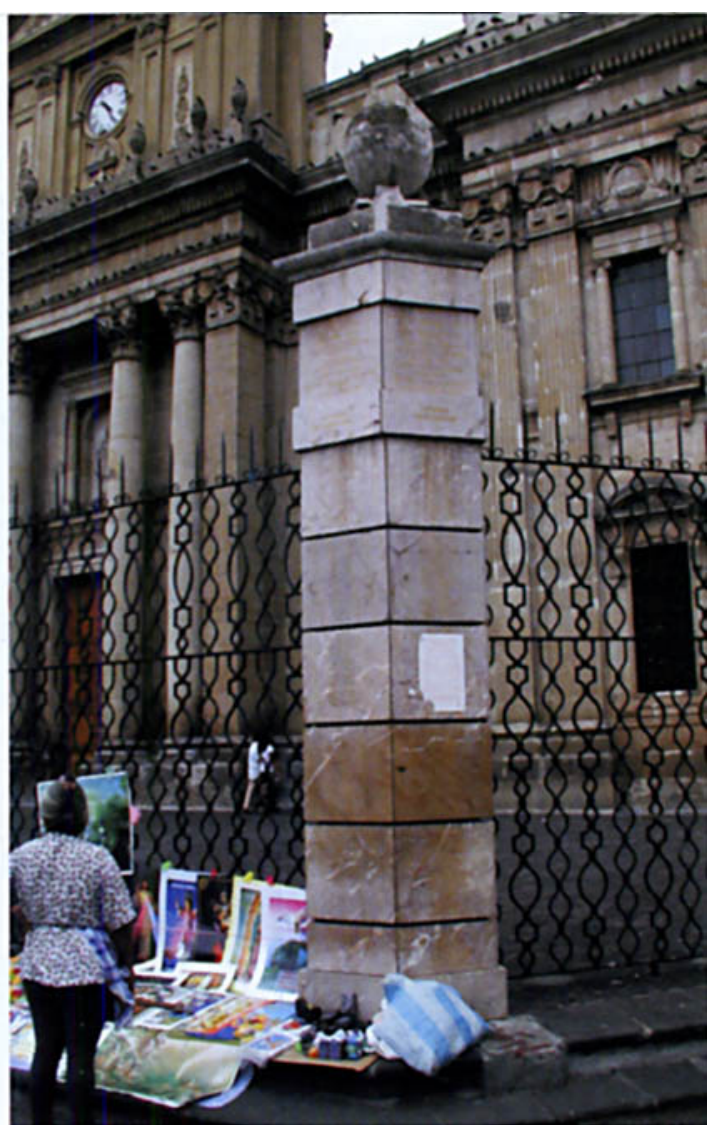

(B)

(C)

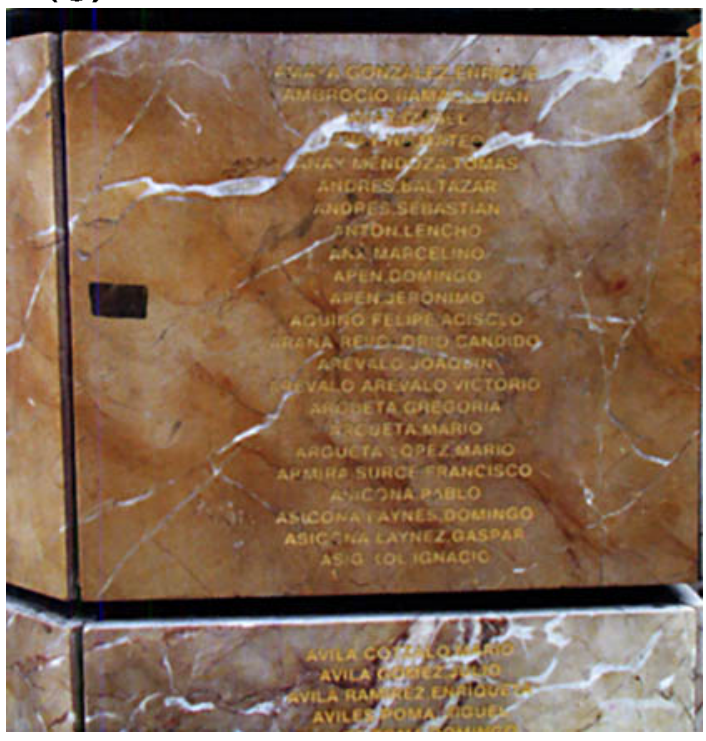

norms. Traditional clothing and cultural practices that have been passed from generation to generation for hundreds of years will be replaced as outside cultures and commercialization dilute the local cultural fabric. Like the volcanoes that have withstood the test of time, however, let us hope that throughout the highland region isolated pockets of the Mayan culture will be preserved and withstand these outside pressures. 


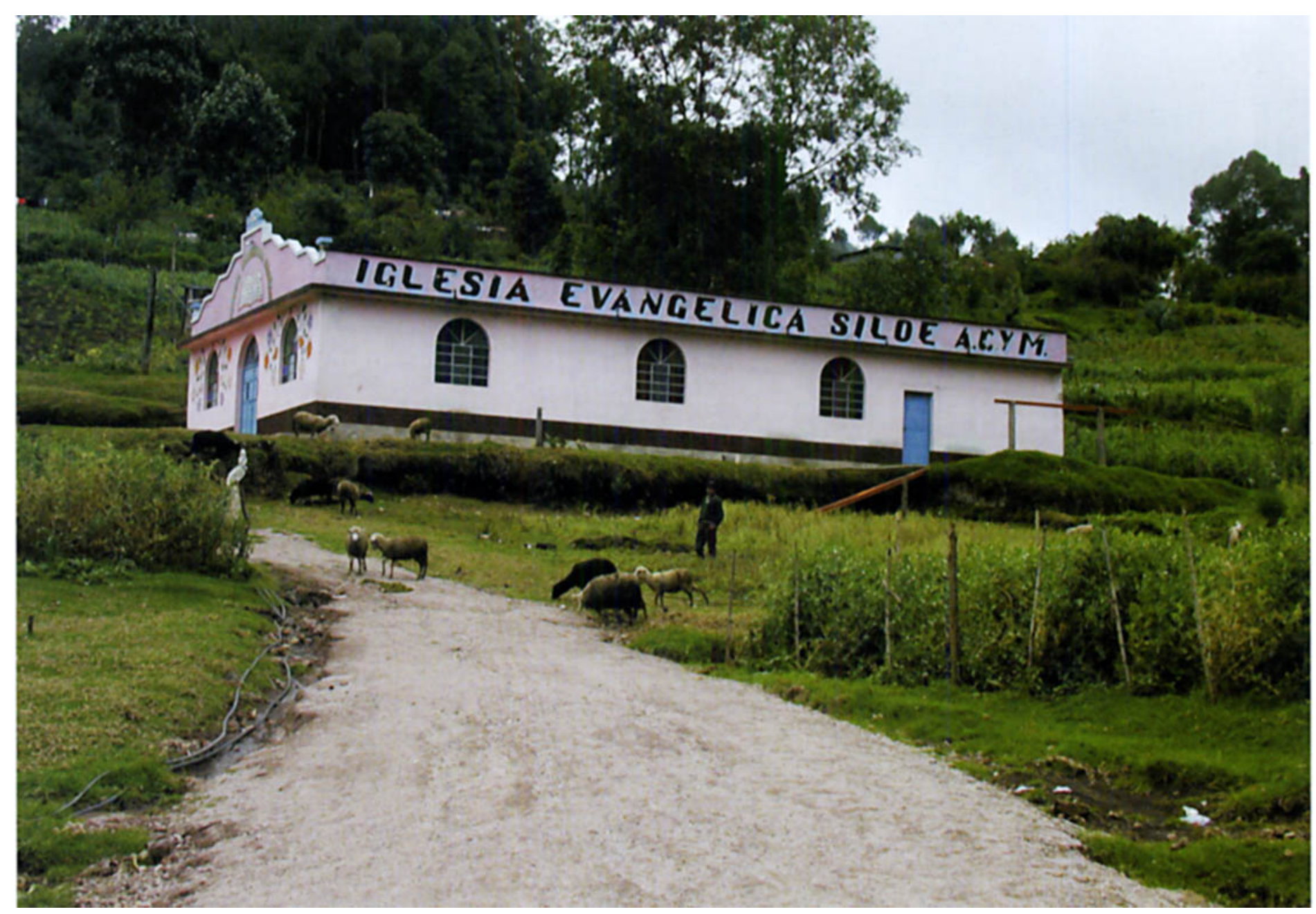

Figure 25: One of many Protestant churches seen on the road between Antigua and Lake Atitlan.

\section{Acknowuledginent}

The author extends his appreciation to the anonymous reviewers for their feedback on an earlier draft of this article.

\section{References / Further Readings}

Central Intelligence Agency. 2006. "The World Factbook Guatemala." Updated on January 10. http://www.odci.gov/cia/publi cations/factbook/geos/gt.html.

Global Exchange. 2005. “Fair Trade Coffee." Updated on April 1. http://www.globalexchange.org /campaigns/fairtrade/coffee/

Handy, Jim. 2004. "Chicken Thieves, Witches, and Judges: Vigilante Justice and Customary Law in Guatemala." Journal of Latin
American Studies. vol 36, pp.533562.

Lovell, W. George and Christopher $\mathrm{H}$. Lutz. 1996. "'A Dark Obverse': Maya Survival in Guatemala, 1520-1994." Geographical Review. vol 86, pp.398-408.

Mitchell, John. 2001. "In the Image of Spain: Historic Antigua." World and $I$. vol 16, pp.86-93.

Organic Consumers Association. 2005. "Coffee Crisis: Starbucks/Fair Trade Campaign." web site visited June 17. http://www.organicconsumers.o $\mathrm{rg}$ /starbucks/

Ross, Amy. 2004. "Truth and Consequences in Guatemala."
Geojournal. vol 60, pp.73-79.

Steinberg, Michael K., Carrie Height, Rosemary Mosher, and Mathew Bampton. 2005. "Mapping Massacres: GIS and State Terror in Guatemala." Geoforum. vol 37, pp. 62-68.

Steinberg, Michael and Matthew Taylor. 2003. "Public Memory and Political Power in Guatemala's Post-Conflict Landscape." Geographical Review. vol 93, pp.449-468.

USGS. 2002. "Major Volcanoes of Guatemala." Updated on February 13.

Http://vulcan.wr.usgs.gov/Volc anoes/Guatemala. 